\title{
Temperature and relative humidity influence the ripening descriptors of Camembert-type cheeses throughout ripening
}

\author{
M.-N. Leclercq-Perlat, ${ }^{*}{ }^{1}$ M. Sicard, ${ }^{*} \dagger$ N. Perrot,${ }^{*} \dagger$ I. C. Trelea, ${ }^{*} \dagger$ D. Picque,${ }^{*} \dagger$ and G. Corrieu* ${ }^{*} \dagger$ \\ *UMR GMPA, INRA 0782, 1 avenue Lucien Brétignières, 78850 Thiverval-Grignon, France. \\ †UMR GMPA, AgroParisTech, 1 avenue Lucien Brétignières, 78850 Thiverval-Grignon, France
}

\begin{abstract}
Ripening descriptors are the main factors that determine consumers' preferences of soft cheeses. Six descriptors were defined to represent the sensory changes in Camembert cheeses: Penicillium camemberti appearance, cheese odor and rind color, creamy underrind thickness and consistency, and core hardness. To evaluate the effects of the main process parameters on these descriptors, Camembert cheeses were ripened under different temperatures $\left(8,12\right.$, and $\left.16^{\circ} \mathrm{C}\right)$ and relative humidity (RH; 88, 92, and 98\%). The sensory descriptors were highly dependent on the temperature and $\mathrm{RH}$ used throughout ripening in a ripening chamber. All sensory descriptor changes could be explained by microorganism growth, $\mathrm{pH}$, carbon substrate metabolism, and cheese moisture, as well as by microbial enzymatic activities. On d 40 , at $8^{\circ} \mathrm{C}$ and $88 \% \mathrm{RH}$, all sensory descriptors scored the worst: the cheese was too dry, its odor and its color were similar to those of the unripe cheese, the underrind was driest, and the core was hardest. At $16^{\circ} \mathrm{C}$ and $98 \% \mathrm{RH}$, the odor was strongly ammonia and the color was dark brown, and the creamy underrind represented the entire thickness of the cheese but was completely runny, descriptors indicative of an over ripened cheese. Statistical analysis showed that the best ripening conditions to achieve an optimum balance between cheese sensory qualities and marketability were $13 \pm 1^{\circ} \mathrm{C}$ and $94 \pm 1 \% \mathrm{RH}$.
\end{abstract}

Key words: cheese ripening, ripening descriptors, temperature, relative humidity

\section{INTRODUCTION}

Among the environmental parameters that affect the ripening of Camembert-type cheese, temperature, relative humidity (RH), and the composition of the gaseous atmosphere in the ripening chamber have the most effect on sensory properties (von Weissenfluh and Puhan,

Received September 30, 2014

Accepted October 23, 2014.

${ }^{1}$ Correspodning author: perlat@grignon.inra.fr
1987; Choisy et al., 2000; Ramet, 2000). These previous studies highlighted the predominant role of temperature and reported that small increases in temperature can accelerate cheese ripening but can also produce offflavor components or inconsumable products. This is in agreement with similar studies on Cheddar (Hannon et al., 2005) and Reggianito Argentino cheeses (Sihufe et al., 2010). Bonaiiti et al. (2004) showed that temperature and RH influence creamy underrind thickness and the consistency of a smear cheese: at $16^{\circ} \mathrm{C}$ under $100 \%$ $\mathrm{RH}$, the underrind became completely runny after $20 \mathrm{~d}$ of ripening. It is recognized that the sensory properties of soft cheeses, such as surface-coating appearance, rind color, and cheese odor, are essential because they determine the choice and preferences of consumers (Dufossé et al., 2005).

To our knowledge, no research on the ripening conditions of Camembert-type cheeses has yet focused on the influence of ripening temperature and $\mathrm{RH}$ on ripening properties. Knowledge is lacking on the links between microbiological and physicochemical phenomena and the changes in cheese sensory properties. According to Perrot et al. (2004) and Sicard et al. (2011), cheesemakers often play an important role in this field. In factories, they may use instrumental measurements and empirical sensory perceptions at the same time (Perrot et al., 2004; Picque et al., 2006), and they may interact with automatic systems to assess the sensory properties of the cheeses and to monitor the ripening process. According to Lemoine (2001), the cheese-maker's assessment and reasoning still play a major role in the cheese ripening process, especially concerning sensory property control. Recently, Sicard et al. (2011) showed that it is possible to study the Camembert ripening process by macroscopic evolutions of cheeses evaluated from an expert's point of view. Those authors established a correlation of $76 \%$ between the microbiological, physicochemical, and biochemical data and the sensory phases measured according to expert knowledge.

The aim of this study was to evaluate the effects of ripening temperature $(\boldsymbol{\theta})$ and $\mathrm{RH}$ on the development of sensory properties in Camembert-type cheeses throughout their ripening (from d 0 to 40) for the same 
set of cheese-making runs. The sensory ripening descriptors were studied in association with the microbial and physicochemical evolutions that occur during ripening.

\section{MATERIALS AND METHODS}

\section{Camembert Cheese-Making and Ripening}

The microorganisms used (Kluyveromyces marxianus, Geotrichum candidum, Penicillium camemberti, and Brevibacterium aurantiacum) and the cheese-making process were described previously (Leclercq-Perlat et al., 2012). Surface-mold-ripened soft cheeses (100 cheeses per cheese-making run, each weighing $300 \pm$ $20 \mathrm{~g})$ were manufactured in a sterile environment. The cheeses were aseptically transferred to a previously sterilized ripening chamber. After $24 \mathrm{~h}$ at $12^{\circ} \mathrm{C}$ and 85 $\pm 1 \% \mathrm{RH}$, they were maintained at 8,12 , or $16^{\circ} \mathrm{C}$ and 88,92 , or $98 \% \mathrm{RH}$, with a periodically renewed atmosphere. To do this, the ripening chamber was sealed on d 0 . The concentration of $\mathrm{CO}_{2}$ increased during ripening and was automatically decreased to $0.1 \%$ when it reached $0.5 \%$ by injecting humid sterile air (Picque et al., 2006). The cheeses were turned on d 5 . On d 13, they were maintained at $12^{\circ} \mathrm{C}$ and $85 \% \mathrm{RH}$ for $24 \mathrm{~h}$. On $\mathrm{d} 14$, the cheeses were then wrapped in a reference wrap (CdL, Amcor Flexibles, Barbézieux, France) and ripened at $4^{\circ} \mathrm{C}$ until d 40 . This wrap was described by Picque et al. (2010).

\section{Sensory Analysis Performed on the Cheeses}

Sensory analyses were performed on each cheese sample under the same light and temperature (14 \pm $1^{\circ} \mathrm{C}$ ) conditions. Sensory evaluation was performed by 5 assessors according to the methodology used by Sicard et al. (2011). Each expert assessed each cheese, taking 5 descriptors generally used by cheese-makers into account, and scored descriptors on a scale from 1 to 5 (Table 1). Six sessions were devoted to training and evaluation before validating the panel's performance (Sicard et al., 2011).To determine the progress of Camemberttype cheese ripening, the appearance of the cheese $(P$. camemberti coating density and surface covering) was assessed as previously described by Bonaiti et al. (2004) and Sicard et al. (2011). The appearance of P. camemberti was assessed in terms of mycelium density and uniformity, varying from 1 (less than $10 \%$ of the cheese surface covered by $P$. camemberti mycelium) to 5 (more than $90 \%$ of the surface covered by $P$. camemberti). In addition, for each cheese sample, cheese odor, rind color under the $P$. camemberti coating, underrind consistency $\left(\mathbf{C}_{\mathbf{U R}}\right)$, and core hardness $\left(\mathbf{H}_{\text {core }}\right)$ on d 14 and 40 were considered. The greatest difference between 2 panelists for each sensory descriptor was $<0.2$. The overall cheese odor varied from fresh cheese (score 1) to ammonia (score 5); the typical odor of Camembert corresponded to a score of 3 . Cheese color under the $P$. camemberti coating varied from white (score 1) to dark brown (score 5); the typical color (cream) of a Camembert corresponded to a score of 3. Creamy underrind thickness is a key factor that characterizes progress of Camembert ripening (Leclercq-Perlat et al., 2004a, 2006, 2012), but its assessment requires destruction of the cheese. Consequently, cheese-makers use another descriptor, $\mathrm{C}_{\mathrm{UR}}$, that characterizes the texture of the ripened part of the cheese, as highlighted by Sicard et al. (2011). The creamy underrind thickness $\left(\mathbf{T}_{\mathbf{U R}}\right.$, $\mathrm{mm}$ ) was measured using a decimeter with an accuracy of $0.2 \mathrm{~mm}$. The underrind consistency (Picque et al., 2010) varied from dry (score 1) to very runny (score 5). The $\mathrm{H}_{\text {core }}$, characterizing the texture of the core part, was estimated by the ease with which the cheese was ground with a mortar and pestle. This hardness varied from very soft (score 1) to very hard (score 5). To simplify the analysis, only 2 characteristic days of ripening were considered: wrapping day (d 14) and the end of ripening (d 40), corresponding to the end of shelf-life for the cheeses.

\section{Experimental Design}

The effects of $\theta$ and $\mathrm{RH}$ on cheese sensory descriptors were examined using a 2-factor, 3-level complete factorial experimental design $\left(3^{2}\right)$ as described by Leclercq-

Table 1. Definition and score of the descriptors used to evaluate the Camembert-type cheese ripening process

\begin{tabular}{|c|c|c|c|c|c|c|}
\hline \multirow[b]{2}{*}{ Descriptor } & \multirow[b]{2}{*}{ Notation } & \multicolumn{5}{|c|}{ Scale and reference } \\
\hline & & 1 & 2 & 3 & 4 & 5 \\
\hline PC coverage ${ }^{1}$ & $\mathrm{~N}_{\mathrm{PC}}$ & $<10 \%$ & $25 \%$ & $50 \%$ & $75 \%$ & $>90 \%$ \\
\hline Overall odor & Odor & Fresh cheese & Musty & Camembert & Camembert ammonia & Ammonia \\
\hline Rind color & Color & White & Cream & Dark cream & Light brown & Dark brown \\
\hline Underrind consistency & $\mathrm{C}_{\mathrm{UR}}$ & Very dry & Dry & Soft & Soft with runny edge & Runny \\
\hline Core hardness & $\mathrm{H}_{\text {core }}$ & Very soft & Soft & Medium & Hard & Very hard \\
\hline
\end{tabular}

${ }^{1} \mathrm{PC}=$ Penicillium camemberti. 
Table 2. Descriptors of Penicillium camemberti appearance ${ }^{1}$ obtained for each temperature $\left(\theta,{ }^{\circ} \mathrm{C}\right)$ and relative humidity (RH, \%) used during Camembert-type cheese ripening

\begin{tabular}{|c|c|c|c|c|c|}
\hline Run & $\theta\left({ }^{\circ} \mathrm{C}\right)$ & $\mathrm{RH}(\%)$ & $t_{\mathrm{PCm}}$ & $\mathrm{N}_{\mathrm{PC} 14}$ & $\mathrm{~N}_{\mathrm{PC} 40}$ \\
\hline 1 & 8 & 88 & 10 & 2 & 2 \\
\hline 2 & 8 & 92 & 10 & 2 & 3 \\
\hline 3 & 8 & 98 & 9 & 3 & 2 \\
\hline 4 & 8 & 98 & 9 & 3 & 2 \\
\hline 3 and 4 & 8 & 98 & 9 & 3 & 2 \\
\hline 5 & 12 & 88 & 6 & 4 & 5 \\
\hline 6 & 12 & 92 & 4.5 & 5 & 5 \\
\hline 7 & 12 & 92 & 5 & 5 & 5 \\
\hline 8 & 12 & 92 & 5 & 5 & 5 \\
\hline 9 & 12 & 92 & 4.5 & 5 & 5 \\
\hline 10 & 12 & 92 & 5 & 5 & 5 \\
\hline 6 to 10 & 12 & 92 & 5 & 5 & 5 \\
\hline 11 & 12 & 98 & 4 & 4 & 3 \\
\hline 12 & 16 & 88 & 3 & 4 & 2 \\
\hline 13 & 16 & 88 & 3 & 4 & 2 \\
\hline 12 and 13 & 16 & 88 & 3 & 4 & 2 \\
\hline 14 & 16 & 92 & 3 & 3 & 3 \\
\hline 15 & 16 & 98 & 3 & 2 & 1 \\
\hline
\end{tabular}

${ }^{1} \mathrm{t}_{\mathrm{PCm}}{ }^{=}$day on which $P$. camemberti mycelium is visually detected by the panel $(\mathrm{SD}=0.5 \mathrm{~d}) ; \mathrm{N}_{\mathrm{PC} 14}$ and $\mathrm{N}_{\mathrm{PC} 40}=$ the appearance notation on d 14 (before wrapping) and on d 40 (end of ripening), respectively. Values in bold are the average of each descriptor for runs carried out under the same conditions of ripening.

Perlat et al. (2012). The 9 combinations of $\theta$ and $\mathrm{RH}$ are shown in Tables 2 and 3. The levels of each factor used were 8,12 , and $16^{\circ} \mathrm{C}$ for $\theta$ and 88,92 , and $98 \%$ for $\mathrm{RH}$. These levels were chosen according to the range of $\theta$ and RH generally used for Camembert cheese ripening. Because the experiments took place over a long period, the runs corresponding to the central point of the experimental design $\left(12^{\circ} \mathrm{C}, 92 \% \mathrm{RH}\right)$ were quintupled (runs 6 to 10). The runs under $8^{\circ} \mathrm{C}$ and $98 \% \mathrm{RH}$ (runs 3 and 4 ) and those under $16^{\circ} \mathrm{C}$ and $88 \% \mathrm{RH}$ (runs 12 and 13) were duplicated. The remaining runs were done just once.

\section{Statistical Analyses}

For the runs made under the same conditions (runs 3 and 4 ; runs 6 to 10 , and runs 12 and 13), sensory descriptors were compared by a 2 -factor (time and trial) ANOVA. The hypotheses examined were the equality of the trials and the absence of any interactions. This test was significant for the risk $\alpha\left[\alpha=1-P\left(F_{\text {obs }}<\right.\right.$ $\left.\left.F_{\text {crit }}\right)\right] \leq 0.01$, where $P$ is the $P$-value, $F_{\text {obs }}$ is the Fisher coefficient obtained with the observed values, and $F_{\text {crit }}$ is that obtained from the Student table of the degrees of freedom of the relationship. To control the equality of trials, the test power $(1-\beta)$, representing the risk of a false interpretation, was determined according to Mann and Whitney's method (Cohen, 1992). This power risk must be $>0.9$ for the interpretation of this test to be considered accurate. The general linear model within Statistica software (StatSoft, Paris, France) was performed to calculate quadratic models and to determine the influence of the 2 factors $(\theta, \mathrm{RH})$ on each sensory descriptor. The nonsignificant terms were omitted one by one using the stepwise backward procedure (Statistica). Consequently, only terms significant at $99 \%$ of the confidence level $(P<0.01)$ were considered. The 3 -dimensional response surfaces of each descriptor in relation to $\theta$ and $\mathrm{RH}$ were plotted to illustrate the main and interactive effects. These effects can be linear, quadratic, or interactive.

\section{RESULTS AND DISCUSSION}

For all runs, P. camemberti appearance (absence of visible mycelia), overall odor (fresh cheese), and rind color (white) scored 1 on $\mathrm{d}$ 0, and $\mathrm{H}_{\text {core }}$ scored 3 (medium). For these descriptors, the standard deviations were less than 0.2. The underrind did not exist on $\mathrm{d} 0$.

\section{Description of Cheese Ripening at $12^{\circ} \mathrm{C}$ and $92 \%$ RH: Reproducibility}

The reproducibility of cheese ripening descriptors was studied for runs 6 to 10 carried out under $12^{\circ} \mathrm{C}$ and $92 \% \mathrm{RH}$ (Table 2). The hypotheses of equality of the means were highly satisfactory $[1-\alpha=0.99$ and the test power $(1-\beta)=0.94]$.

The time at which the first mycelia were observed in the rind or along the edge of the cheeses $\left(\mathbf{t}_{\mathbf{P C m}} ; \mathbf{d}\right)$ defined the growth of $P$. camemberti mycelia, and the appearance of the $P$. camemberti $\left(\mathbf{N}_{\mathbf{P C}}\right)$ covering was defined in terms of mycelium density and uniformity of mycelium distribution on the surface. Regardless of 
Table 3. Scores of ripening descriptors ${ }^{1}$ of Camembert-type cheese ripening on d 14 (before wrapping) and on d 40 (end of ripening) obtained for each temperature $\left(\theta,{ }^{\circ} \mathrm{C}\right)$ and relative humidity $(\mathrm{RH}, \%)$

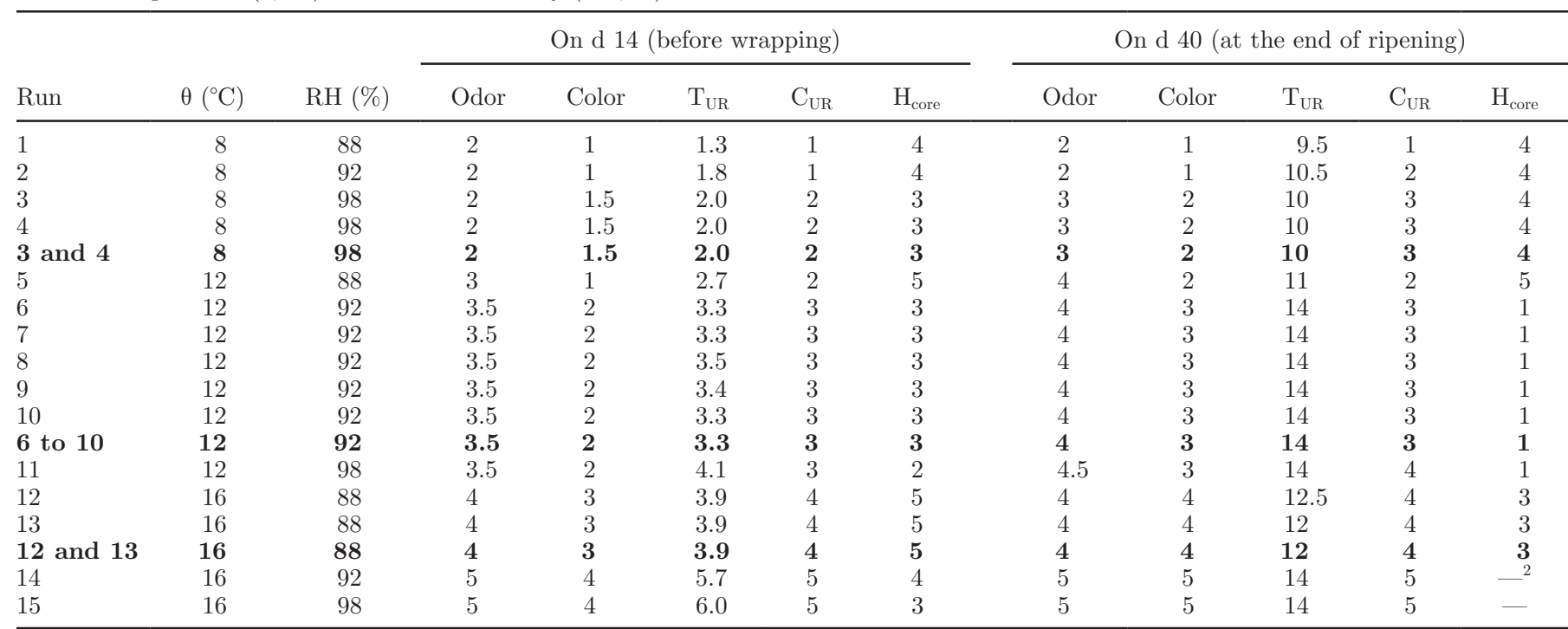

${ }^{1}$ Overall rind cheese odor varied from fresh cheese (score of 1 ) to ammonia (score of 5 ); cheese color under the P. camemberti coating varied from white (score of 1 ) to dark brown (score of 5); $\mathrm{T}_{\mathrm{UR}}=$ underrind thickness $(\mathrm{mm} ; \mathrm{SD}=0.5 \mathrm{~mm}) ; \mathrm{C}_{\mathrm{UR}}=$ underrind consistency, which varied from a dry (score of 1 ) to a very runny underrind (score 5 ); $\mathrm{H}_{\text {core }}=$ cheese core hardness, estimated by the ease with which the cheese could be ground with a mortar and pestle from very soft (score 1) to very hard (score 5). Values in bold are the average of each descriptor for runs carried out under the same conditions of ripening.

${ }^{2}$ Core was totally ripened and liquid and assessors could not evaluate the hardness.

the central point runs (6 to 10), P. camemberti mycelia became visible on d 5 . From d 14 to 40, all cheeses were covered with a thick dense and white mycelium, giving the maximum score (Table 2).

On d 14, the overall odor and rind color were "camembert" and "cream," respectively, whereas on d 40, they were "camembert-ammonia" and "dark cream," respectively (Table 3 ).

On d 14 and 40, $\mathrm{H}_{\text {core }}$ was medium and $\mathrm{C}_{\mathrm{UR}}$ was soft. The value of $\mathrm{T}_{\mathrm{UR}}$ was close to $3.3 \mathrm{~mm}$ on $\mathrm{d} 14$ and took up the entire cheese thickness on d 40 (Table 3). For the 5 runs carried out under standard ripening conditions (runs 6 to 10), all descriptors were statistically identical with $99 \%$ confidence levels.

\section{Influence of Temperature and RH on Cheese Ripening Descriptors}

The scores of ripening descriptors are reported in Table 2 for $P$. camemberti appearance and in Table 3 for the other descriptors. Table 4 reports the main significant relationships established between the descriptors and $\theta$ and RH. Figures 1 and 2 correspond to 3 -dimensional response surface plots of the descriptors as a function of $\theta$ and $\mathrm{RH}$.

\section{Appearance of Penicillium camemberti}

The time at which mycelium appeared $\left(t_{\mathrm{PCm}}\right)$ was independent of $\mathrm{RH}$ and only related to $\theta$ (Table 2).
As shown in Table 4, the appearance of $P$. camemberti mycelium on d $14\left(\mathbf{N}_{\text {PC14 }}\right)$ was a function of $\theta$ (linear and quadratic terms), RH (linear term), and $\theta$ and $\mathrm{RH}$ (interactive term); on d $40\left(\mathbf{N}_{\mathbf{P C} 40}\right)$, it was related to $\theta$ and $\mathrm{RH}$ (linear and quadratic terms). The $\mathrm{N}_{\mathrm{PC} 14}$ surface response (Figure 1A) showed a main effect of $\theta$. In fact, $\mathrm{N}_{\mathrm{PC} 14}$ increased with $\theta$ from $8^{\circ} \mathrm{C}$ to approximately $12^{\circ} \mathrm{C}$ and decreased thereafter (quadratic effect). The $\mathrm{RH}$ effect was relatively smaller and depended on $\theta$, revealing an interactive effect: $\mathrm{N}_{\mathrm{PC} 14}$ increased with $\mathrm{RH}$ at low $\theta$ and decreased with $\mathrm{RH}$ at high $\theta$. The $\mathrm{N}_{\mathrm{PC} 40}$ surface response (Figure 1B) showed the importance of the quadratic effects of $\theta$ and $\mathrm{RH}$ : $\mathrm{N}_{\mathrm{PC} 40}$ reached its maximum value for a $\theta$ of approximately $12^{\circ} \mathrm{C}$ and a $\mathrm{RH}$ of approximately $93 \%$.

Ripening in the chamber at $16^{\circ} \mathrm{C}$ under $98 \% \mathrm{RH}$ promoted $P$. camemberti sporulation, as previously shown by Leclercq-Perlat et al. (2012). Hardy et al. (2000) and Lenoir et al. (1985) reported that optimal mycelium growth is obtained under 90 to $94 \% \mathrm{RH}$ for a temperature between 10 and $14^{\circ} \mathrm{C}$. Moreover, P. camemberti mycelium does not grow well at higher RH (Ramet, 2000). The white and down coating of the Camembert surface disappears when the $\mathrm{RH}$ of the ripening room exceeds $95 \%$ at 12 to $14^{\circ} \mathrm{C}$, even if these conditions last only 2 or $3 \mathrm{~d}$. However, neither the $P$. camemberti visual appearance nor the $P$. camemberti spore count gives an accurate idea of mycelium growth and development, the first due to limitations of the human eye (saturation 
when $P$. camemberti coating is complete) and the second because of the destruction of mycelium. Indeed, $P$. camemberti sporulation is accelerated throughout ripening by the temperature (Leclercq-Perlat et al., 2012, 2013). In the current study, the higher the temperature , the earlier growth of $P$. camemberti occurred and the earlier its concentration became maximal. Moreover, at $16^{\circ} \mathrm{C}$ and $98 \% \mathrm{RH}, P$. camemberti mycelium appeared damaged due to the disruption of the equilibrium between $P$. camemberti and G. candidum in favor of the yeast, whereas $P$. camemberti spore concentration was higher (Leclercq-Perlat et al., 2013).

\section{Overall Cheese Odor}

On d 14, cheese odor was described as "musty" at $8^{\circ} \mathrm{C}$, "camembert" at $12^{\circ} \mathrm{C}$, and "camembert-ammonia" at $16^{\circ} \mathrm{C}$ (Table 3). This descriptor was related to $\theta$ (individual and quadratic terms), $\mathrm{RH}$ (individual term), and $\theta$ and RH (interactive term; Table 4). In addition, odor uniformly increased at $\theta$ between 8 and $16^{\circ} \mathrm{C}$, whereas the $\mathrm{RH}$ effect was almost negligible at $8^{\circ} \mathrm{C}$ and positive at $16^{\circ} \mathrm{C}$ (Figure 1C). On d 40, rind odor remained "musty" at $8^{\circ} \mathrm{C}$ under 88 and $92 \% \mathrm{RH}$, but became "camembert" under $98 \%$ RH. It was described as "camembert-ammonia" at $12^{\circ} \mathrm{C}$ regardless of $\mathrm{RH}$ and at $16^{\circ} \mathrm{C}$ and $88 \% \mathrm{RH}$. It was described as "ammonia" at $16^{\circ} \mathrm{C}$ under 92 and $98 \% \mathrm{RH}$. This descriptor was a function of $\theta$ (individual and quadratic terms) and $\mathrm{RH}$ (linear term; Table 4). The odor increased with $\theta$, and $\mathrm{RH}$ had a constant positive linear effect, regardless of $\theta$ (Figure 1D).

An increase in $\theta$ induced better growth of the ripening microorganisms, mainly G. candidum and P. camemberti mycelium. When $\theta$ was $>10^{\circ} \mathrm{C}, B$. aurantiacum maximal exponential growth rate was reached on d 15 under $12^{\circ} \mathrm{C}$ and $92 \% \mathrm{RH}$, and just after wrapping, or on d 12 at $16^{\circ} \mathrm{C}$ and $88 \% \mathrm{RH}$ (Leclercq-Perlat et al., 2012). A better expression of these enzymatic activities (promoting proteolysis and lipolysis) can also be induced by RH (Choisy et al., 2000). Moreover, an increase in temperature and $\mathrm{RH}$ can lead to an increase in the amount and variety of aroma compounds (Sablé and Cottereau, 1999; McSweeney and Sousa, 2000; Le Quéré, 2011).

By d 14, rind color increased with $\theta$, from white, corresponding to a cheese with very little ripening $\left(8^{\circ} \mathrm{C}\right.$ under 88 and $92 \% \mathrm{RH}$ or $12^{\circ} \mathrm{C}$ under $\left.88 \% \mathrm{RH}\right)$, to brown $\left(16^{\circ} \mathrm{C}\right.$ under 92 and $\left.98 \% \mathrm{RH}\right)$. By d 40, this color turned from white $\left(8^{\circ} \mathrm{C}\right.$ under 88 or $\left.92 \% \mathrm{RH}\right)$ to dark brown, an unacceptable color for a Camembert cheese $\left(16^{\circ} \mathrm{C}\right.$ under 92 or $\left.98 \% \mathrm{RH}\right)$. 
A

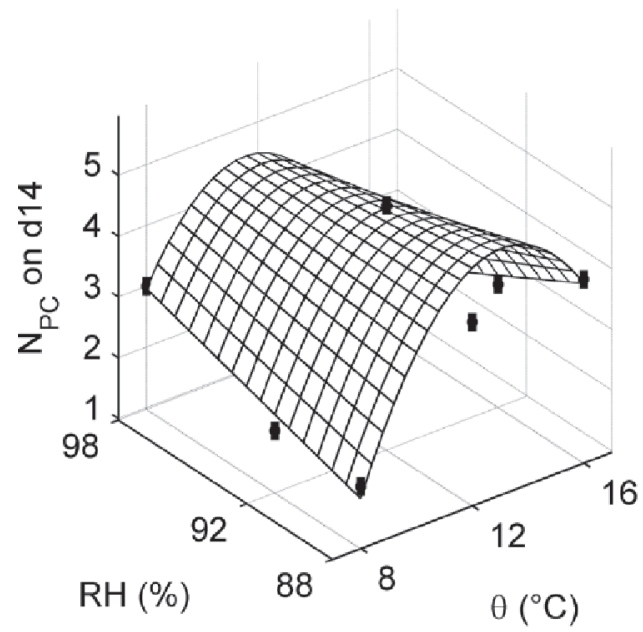

C

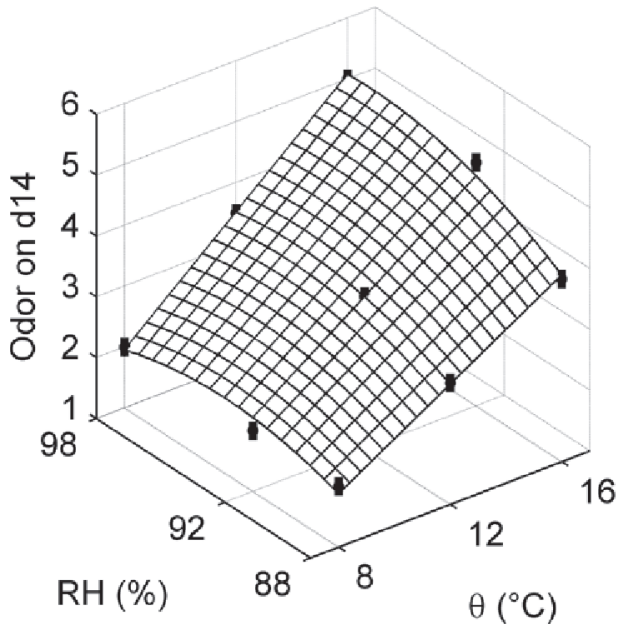

E

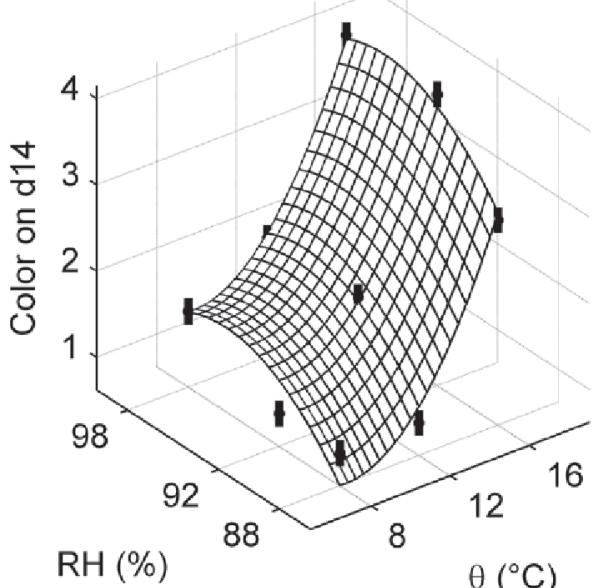

B

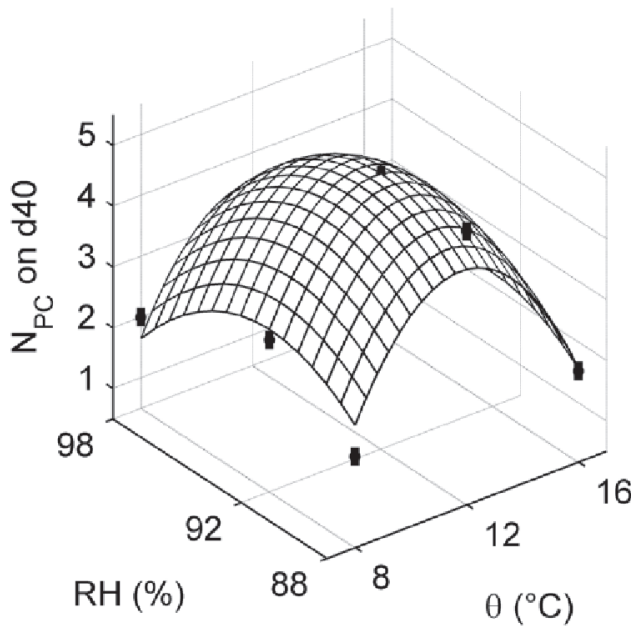

D

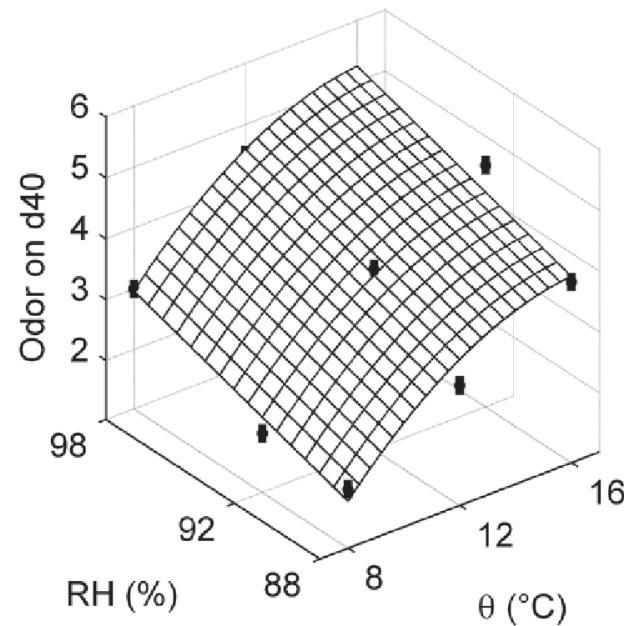

F

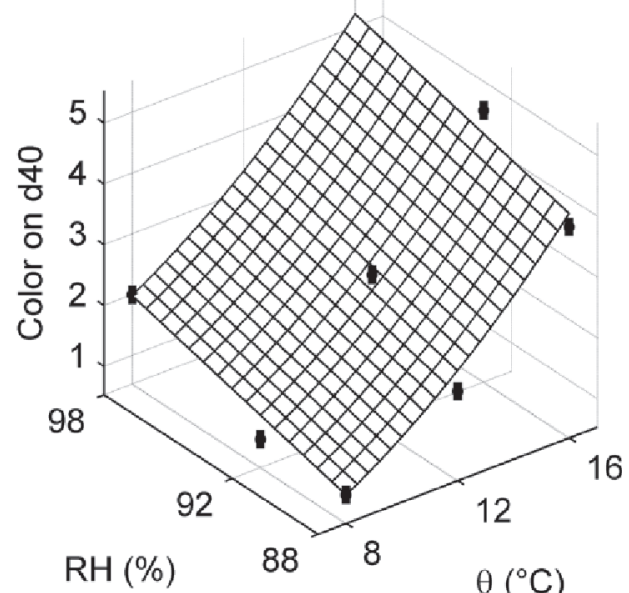

Figure 1. Estimated response surface plots of some ripening descriptors as a function of temperature $\left(\theta,{ }^{\circ} \mathrm{C}\right)$ and relative humidity $(\mathrm{RH}, \%)$. Penicillium camemberti appearance notation ( $\mathrm{N}_{\mathrm{P}}$; score) on (A) d 14 and (B) d 40; odor (score) on (C) d 14 and (D) d 40; and color (score) on (E) d 14 and (F) d 40. 
OUR INDUSTRY TODAY

A

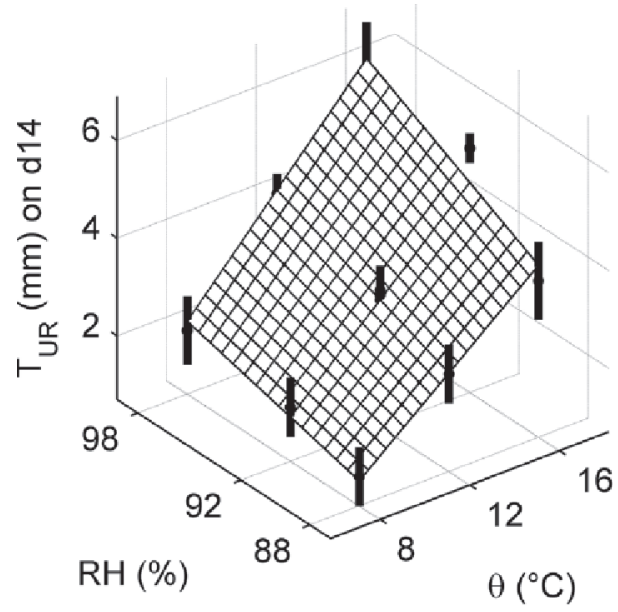

C

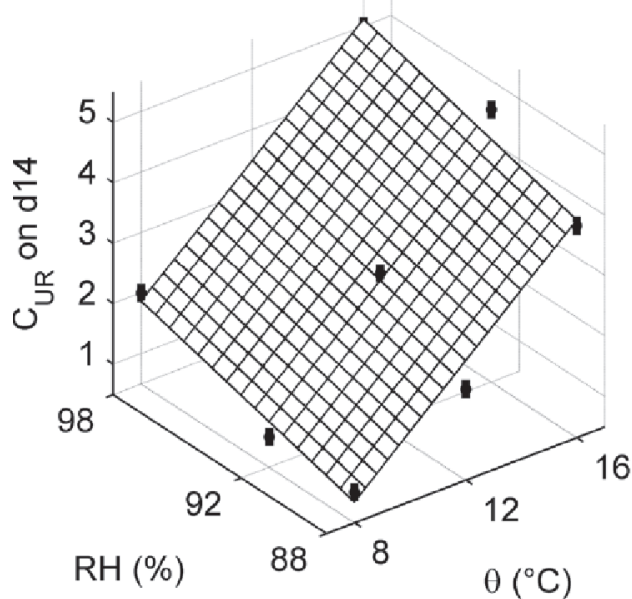

E

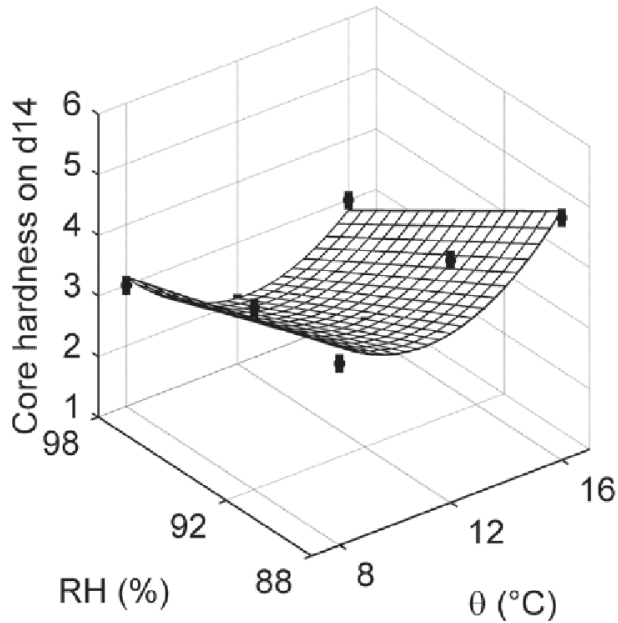

B

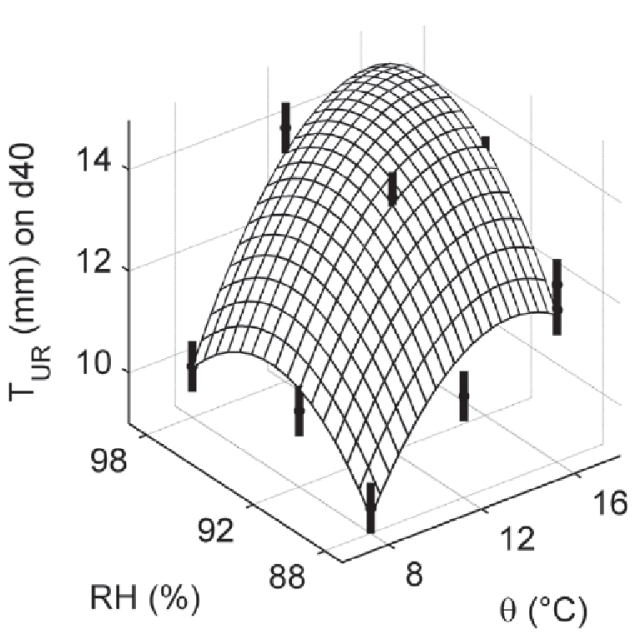

$\mathrm{D}$

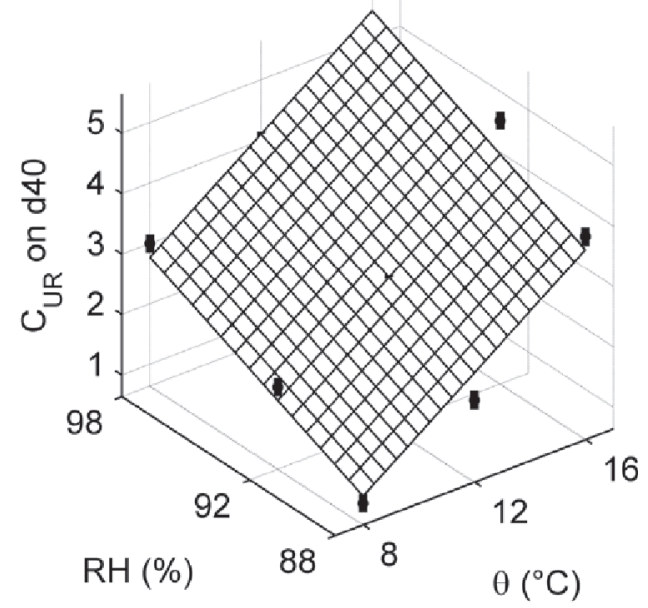

$\mathrm{F}$

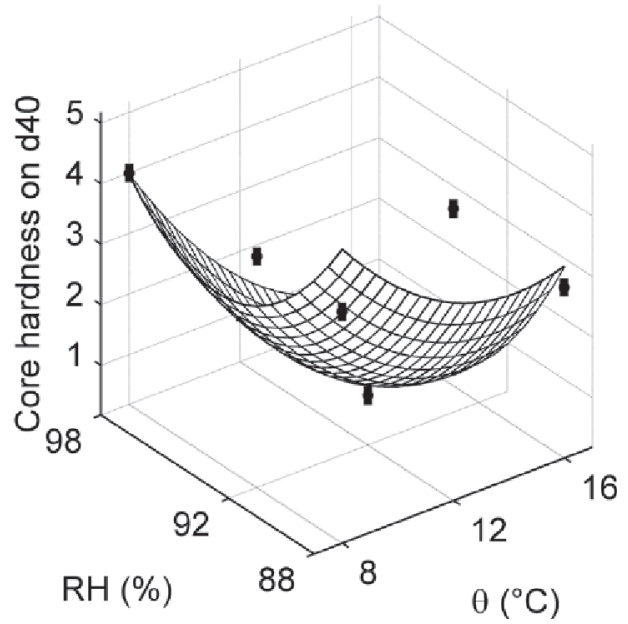

Figure 2. Estimated response surface plots of some ripening descriptors as a function of temperature $\left(\theta,{ }^{\circ} \mathrm{C}\right)$ and relative humidity $(\mathrm{RH}$, \%). Underrind thickness $\left(\mathrm{T}_{\mathrm{UR}}, \mathrm{mm}\right)$ on $(\mathrm{A}) \mathrm{d} 14$ and (B) d 40; underrind consistency $\left(\mathrm{C}_{\mathrm{UR}}\right.$; score) on (C) d 14 and (D) d 40; and core hardness (score) on (E) d 14 and (F) d 40. 


\section{Rind Color}

On d 14, rind color was a function of $\theta$ and $\mathrm{RH}$ (individual and quadratic terms), whereas on d 40, it was related only to $\theta$ and $\mathrm{RH}$ (individual terms; Table 4). Figure $1 \mathrm{E}$ shows the importance of quadratic terms on color on d 14, whereas Figure $1 \mathrm{~F}$ shows that color increased uniformly with $\theta$ and $\mathrm{RH}$ (linear effects) on d 40. Rind color directly depends on the production of pigments by Brevibacterium species (Dufossé et al., 2001). At $8^{\circ} \mathrm{C}$ regardless of $\mathrm{RH}$ or at $12^{\circ} \mathrm{C}$ and $88 \% \mathrm{RH}$, a delay in yeast growth and $P$. camemberti mycelium development was observed $\left(\mathrm{t}_{\mathrm{PCm}}\right.$ in Table 2$)$. Consequently, a delay in rind acidification and $B$. aurantiacum growth was observed (Leclercq-Perlat et al., 2012). The latter authors showed that, on $\mathrm{d} 40$, at $8^{\circ} \mathrm{C}$ and 92 or $98 \% \mathrm{RH}$, B. aurantiacum counts were the lowest (between $6 \times 10^{6}$ and $2 \times 10^{8} \mathrm{cfu} / \mathrm{g}$ ). In contrast, at $16^{\circ} \mathrm{C}$ under 92 or $98 \% \mathrm{RH}$, B. aurantiacum grew better, reaching $8 \times 10^{9} \mathrm{cfu} / \mathrm{g}$, and rind deacidification took place earlier (d 2.5). At $16^{\circ} \mathrm{C}$ under $98 \% \mathrm{RH}, P$. camemberti mycelium disappeared after d 8 , whereas mold sporulation increased (Leclercq-Perlat et al., 2013). These results highlight the dependence of rind color on $\mathrm{RH}$ due to better development of $B$. aurantiacum and a poor coating of $P$. camemberti mycelium when $\mathrm{RH}$ is $>95 \%$. Moreover, indirect positive interactions between yeasts, molds, and B. aurantiacum may increase proteolysis (Bockelmann et al., 1997) and can favor a better development of color (Leclercq-Perlat et al., 2004b; Lecocq et al., 1996).

\section{Underrind Thickness}

On $\mathrm{d} 14, \mathrm{~T}_{\mathrm{UR}}$ increased by approximately $50 \%$ when $\theta$ increased from $8^{\circ} \mathrm{C}$ to $12^{\circ} \mathrm{C}$, whereas it increased by between 32 and $40 \%$ when $\theta$ increased from $12^{\circ} \mathrm{C}$ to $16^{\circ} \mathrm{C}$. On d $14, \mathrm{~T}_{\mathrm{UR}}$ increased from $10 \%\left(8-12^{\circ} \mathrm{C}\right)$ to $15 \%\left(16^{\circ} \mathrm{C}\right)$ when the $\mathrm{RH}$ increased from 88 to $92 \%$, whereas it increased from 9 to $17 \%$ when the $\mathrm{RH}$ increased from 92 to $98 \%$. These results are in agreement with those of Gomes et al. (1998) and Gomes and Malcata (1998), who showed that temperature had a more important effect than $\mathrm{RH}$ for different proteolysis levels. In our study, $\mathrm{T}_{\mathrm{UR}}$ on $\mathrm{d} 14$ was related to $\theta$ (linear term) and $\theta$ and $\mathrm{RH}$ (interactive terms; Table 4 ) and it increased along the $\theta$ axis from 8 to $16^{\circ} \mathrm{C}$; the temperature effect was stronger at higher $\mathrm{RH}$ values (Figure $2 \mathrm{~A})$. At $8^{\circ} \mathrm{C}$ on $\mathrm{d} 40$, regardless of $\mathrm{RH}, \mathrm{T}_{\mathrm{UR}}$ reached around two-thirds of the cheese thickness (Table 3 ). This can be explained by a slowing of growth of all ripening microorganisms and by a limitation of their enzymatic activities due to the excessive drying of the cheese or to temperature (Leclercq-Perlat et al., 2012). Lesage-Meessen and Cahagnier (1998) reported that microbial growth is repressed when the water activity, strongly linked to RH during ripening (Ramet, 2000), is progressively lowered. Regardless of $\theta, \mathrm{T}_{\mathrm{UR}}$ did not increase as much during ripening under $88 \% \mathrm{RH}$ as under 92 or $98 \% \mathrm{RH}$. For other ripening conditions, the entire thickness of the cheese was ripened. This descriptor was related to $\theta$ (quadratic term) and $\mathrm{RH}$ (linear and quadratic terms) and their interactive term. These effects are shown in Figure $2 \mathrm{~B} ; \mathrm{T}_{\mathrm{UR}}$ exhibited a maximum at $14 \pm 1^{\circ} \mathrm{C}$ and $93 \pm 1 \% \mathrm{RH}$.

\section{Underrind Consistency and Core Hardness}

Regardless of $\theta$ under $88 \% \mathrm{RH}$, the score for $\mathrm{C}_{\mathrm{UR}}$ was lower than that obtained at either 92 or $98 \% \mathrm{RH}$ (Table 3 ). Under $8^{\circ} \mathrm{C}$ and $88 \% \mathrm{RH}$ (run 1), the underrind was very dry on d 14 and 40 . Only the central points (runs 6 to 10) had the soft and creamy underrind typical of a Camembert cheese (Table 3). For all $\mathrm{RH}$ at $16^{\circ} \mathrm{C}$, cheeses did not have an acceptable underrind consistency because the underrind had runny edges $(88 \% \mathrm{RH})$ or was completely runny (92 and $98 \% \mathrm{RH}$ ). The underrind consistency that showed almost linear increases along the $\theta$ and RH axes in the considered range (prevailing linear effects without interaction) confirmed the influences of $\theta$ (as the preponderant factor) and $\mathrm{RH}$ on $\mathrm{d} 14$ (Figure 2C) and on d 40 (Figure 2D).

Under $88 \% \mathrm{RH}$ on $\mathrm{d} 14, \mathrm{H}_{\text {core }}$ was hard $\left(\right.$ at $8^{\circ} \mathrm{C}$ ) or very hard (at $12^{\circ} \mathrm{C}$ or $16^{\circ} \mathrm{C}$; Table 3 ). Regardless of $\theta$ under $92 \%$ or $98 \% \mathrm{RH}, \mathrm{H}_{\text {core }}$ remained medium under $88 \% \mathrm{RH}$ on $\mathrm{d} 40$. It remained hard at $8^{\circ} \mathrm{C}$ or very hard at $12^{\circ} \mathrm{C}$ but scored medium at $16^{\circ} \mathrm{C}$. At $12^{\circ} \mathrm{C}$ or $16^{\circ} \mathrm{C}$ under 92 or $98 \% \mathrm{RH}$, the entire cheese thickness was ripened and $\mathrm{H}_{\text {core }}$ could not be scored by the assessors.

On $\mathrm{d} 14, \mathrm{H}_{\text {core }}$ was a function of $\theta$ (individual term) and $\mathrm{RH}$ (interactive term; Figure 2E). This descriptor reached a minimum for $\theta$ that depended on the $\mathrm{RH}$ (interaction): it was approximately $13^{\circ} \mathrm{C}$ for $98 \%$ $\mathrm{RH}$ and approximately $11^{\circ} \mathrm{C}$ for $88 \% \mathrm{RH}$, as shown in Figure 2E. Core hardness decreased with increased $\mathrm{RH}$, and the RH effect was slightly stronger for higher $\theta$. On d 40, it was impossible to determine a relationship between $\mathrm{H}_{\text {core }}$ and ripening conditions because the entire cheese was ripened.

Both $\mathrm{C}_{\mathrm{UR}}$ and $\mathrm{H}_{\text {core }}$ are descriptors of cheese texture. Cheese texture mainly depends on its $\mathrm{pH}$, the entirety of caseins and lipids, and the moisture level (Lawrence et al., 1987). In fact, regardless of ripening conditions, the $\mathrm{pH}$ of the underrind is close to that of the rind (Leclercq-Perlat et al., 2012). This can be explained by the lactate and ammonium concentration gradients 
that exist between the core and the rind (Vassal et al., 1986; Leclercq-Perlat et al., 2004a). Regardless of $\theta$ under $88 \% \mathrm{RH}$, the cheeses were not soft and did not have a creamy underrind due to (1) excessive drying of the cheese; (2) a delay in $K$. marxianus and $G$. candidum growth; (3) lower growth of P. camemberti and $B$. aurantiacum (Leclercq-Perlat et al., 2012, 2013); and (4) lower enzymatic activity as shown by overall cheese odor. In fact, at $16^{\circ} \mathrm{C}$ and $92 \% \mathrm{RH}$ and at 12 or $16^{\circ} \mathrm{C}$ under $98 \% \mathrm{RH}$, the cheese underrind was completely runny, indicative of over-ripening. With the rapid increase of $\mathrm{pH}$ and its consequence on the texture, liquefaction of the underrind can be explained by breakdown of casein and associated enzymatic activities due to faster growth of microorganisms (Leclercq-Perlat et al., 2012, 2013).

The hydrolysis reactions that take place in cheese involve water fixation within the cheese core. Moreover, the breakdown products of caseins are largely watersoluble, and proteolytic activity in cheese is mainly determined by the level of moisture, the temperature of ripening, and changes in $\mathrm{pH}$ throughout ripening (Lawrence et al., 1987; Ramet, 2000).

In addition, changes in underrind consistency can be explained by the enzymatic activity of the surfaceripening flora, although the enzymes remain near their production site; that is, the cheese rind (Noomen, 1983). Kluyveromyces marxianus has only endocellular proteolytic activity (Klein et al., 2002), G. candidum strongly contributes to proteolysis by its extensive enzymatic system (Boutrou et Guéguen, 2005; Boutrou et al., 2006), P. camemberti has a complex proteolytic system that is more active when the $\mathrm{pH}$ of the rind is at least 6.0 (Lenoir et al., 1985; Choisy et al., 2000), and $B$. aurantiacum is well known for its considerable proteolytic activity (Lecocq et al., 1996; Rattray and Fox, 1999). Under $98 \% \mathrm{RH}$ at $12^{\circ} \mathrm{C}$ and 92 or $98 \% \mathrm{RH}$ at $16^{\circ} \mathrm{C}$, Leclercq-Perlat et al. (2012) showed that (1) the death of $K$. marxianus begins earlier (d 25) and is more intensive than under the other ripening conditions; (2) G. candidum growth also began earlier (d 1 to 2), more rapidly reaching its maximal concentration; (3) P. camemberti spore concentrations were the highest, reaching approximately $5.5 \times 10^{6}$ spores/g on d 40 at $16^{\circ} \mathrm{C}$; and (4) B. aurantiacum grew quickly as well, reaching a concentration of more than $1 \times 10^{9} \mathrm{cfu} / \mathrm{g}$. Moreover, a synergy was observed between $G$. candidum and $P$. camemberti, the first allowing an easier assimilation of peptides and AA as carbon sources by $P$. camemberti, leading to a more intense proteolysis in the cheese underrind, confirming the studies of Aziza et al. (2005) and Aziza and Amrane (2006). Underrind consistency is also related to lipid breakdown mainly by
G. candidum and P. camemberti (Lenoir et al., 1985); K. marxianus and B. aurantiacum have no significant lipolytic activities (Leclercq-Perlat et al., 2007). Lipolytic enzyme activities mainly depend on temperature and cheese moisture, which is dependent on RH (Choisy et al., 2000; Ramet, 2000; Leclercq-Perlat et al., 2012). Subsequently, low RH leads to considerable dehydration of the cheese rind by water evaporation from the surface toward the atmosphere, and water diffuses from the cheese core toward the surface at the same time (Simal et al., 2001; Bonaït et al., 2004). This dehydration increased with temperature: under $88 \% \mathrm{RH}$ at $16^{\circ} \mathrm{C}$, the cheese $\mathrm{DM}$ on $\mathrm{d} 14$ and 40 was the greatest, $47 \%$ and $53 \pm 1 \%$, respectively, leading to a slowing of ripening (Leclercq-Perlat et al., 2012). However, regardless of $\mathrm{RH}$ at $8^{\circ} \mathrm{C}$, the core remained hard on d 40 although its DM (42-44\%) did not differ from that of cheese under the other ripening conditions. This could be explained by a slowing of enzymatic reactions occurring in the cheese, probably due to the lower temperature. In contrast, under $98 \% \mathrm{RH}$ at $12^{\circ} \mathrm{C}$ or $16^{\circ} \mathrm{C}$, greater enzymatic activity and lower dehydration cause the cheese underrind to become liquid. Regardless of the temperature under $88 \% \mathrm{RH}$, the cheese water mass loss and the DM of the core were the highest (LeclercqPerlat et al., 2012; study conducted at the same time as the current study and using the same cheeses). Consequently, cheese moisture is strongly influenced by the ripening conditions, confirming the importance of cheese moisture and, consequently, the importance of $\mathrm{RH}$ on core hardness.

\section{CONCLUSIONS}

The sensory properties of Camembert-type cheeses assessed by an expert panel were highly dependent on $\theta$ and RH used throughout ripening. All sensory descriptor changes (overall cheese odor and color, creamy underrind thickness and consistency, core hardness) can be explained by microorganism growth, $\mathrm{pH}$ increase, carbon substrate diffusion and assimilation and cheese moisture, as well as microbial enzymatic activity. All factors were also linked to $\theta$ and $\mathrm{RH}$ established in the ripening chamber at the beginning of the process $(\mathrm{d} 0$ to 14 ). Under $88 \% \mathrm{RH}$ at $8^{\circ} \mathrm{C}$, all sensory descriptors scored the worst on d 40: the cheeses were too dry, their odor and color were similar to those of the cheeses defectively ripened, the underrind was the driest, and the core was hardest. In contrast, under $98 \% \mathrm{RH}$ at $16^{\circ} \mathrm{C}$, the odor and the color of the cheeses were ammonia and dark brown, respectively, and the creamy underrind represented the entire thickness of the cheeses but was completely runny. These descriptors were indicative 
of over-ripened cheeses. The best ripening conditions to obtain an optimum between sensory qualities and cheese ripening properties appeared to be $13^{\circ} \mathrm{C}$ and $94 \% \mathrm{RH}$. Because all of the cheeses were wrapped with the same film and then ripened at $4^{\circ} \mathrm{C}$, we established that the initial ripening conditions in the room (from d 0 to 14) determine the ripening of Camembert-type cheeses under wrapping. This type of study will provide the knowledge necessary (1) to develop a mechanistic model to monitor the Camembert-type cheese ripening process in relation to ripening conditions; (2) to slow down or accelerate the ripening process in relation to market demand; and (3) to correct some of the existing flaws in acceptable cheeses.

\section{ACKNOWLEDGMENTS}

This work was supported by the French Ministry of Research through a contract from the French National Program for Agronomic Research (PNRA). The authors are deeply grateful to F. Lecornué and T. Cattenoz (UMR GMPA, Thiverval-Grignon, France) for their technical assistance and to the 5 assessors for their expertise.

\section{REFERENCES}

Aziza, M., and A. Amrane. 2006. Commensalism during submerged mixed culture of Geotrichum candidum and Penicillium camemberti on glutamate and lactate. Process Biochem. 41:2452-2457.

Aziza, M., C. Couriol, A. Amrane, and R. Boutrou. 2005. Evidences for synergistic effects of Geotrichum candidum on Penicillium camemberti growing in cheese juice. Enzyme Microb. Technol. $37: 218-224$.

Bockelmann, W., C. Fuehr, D. Martin, and K. J. Keller. 1997. Color development by red-smear surface bacteria. Kiel. Milchwirch. Forsch. 49:285-292.

Bonaïti, C., M.-N. Leclercq-Perlat, E. Latrille, and G. Corrieu. 2004. Deacidification by Debaryomyces hansenii of smear soft cheeses ripened under controlled conditions: Relative humidity and temperature influences. J. Dairy Sci. 87:3976-3988.

Boutrou, R., and M. Guéguen. 2005. Interest in Geotrichum candidum for cheese technology. Int. J. Food Microbiol. 102:1-20.

Boutrou, R., L. Kerriou, and J. Y. Gassi. 2006. Contribution for $G e-$ otrichum candidum to the proteolysis of soft cheese. Int. Dairy J. 16:775-783.

Choisy, C., M. Desmazeaud, J. C. Gripon, G. Lamberet, and J. Lenoir. 2000. The biochemistry of ripening. Pages $82-151$ in Cheese-Making: From Science to Quality Assurance. A. Eck and J. C. Gillis, ed. Lavoisier Publishing, Paris, France.

Cohen, J. 1992. A power primer. Psychol. Bull. 112:155-159.

Dufossé, L., P. Galaup, E. Carlet, C. Flamin, and A. Valla. 2005. Spectrocolorimetry in the CIE L*a*b* color as useful for monitoring the ripening process and the qualities of PDO red smear soft cheeses. Food Res. Int. 38:919-924.

Dufossé, L., P. Mahon, and A. Binet. 2001. Assessment of the coloring strength of Brevibacte- rium linens strains: Spectrocolorimetry versus total carotenoid extraction/quantifycation. J. Dairy Sci. 84:354-360.

Gomes, A. M. P., and F. X. Malcata. 1998. Development of probiotic cheese manufactured from goat milk: Response surface analysis via technological manipulation. J. Dairy Sci. 81:1492-1507.
Gomes, A. M. P., M. M. Vieira, and F. X. Malcata. 1998. Survival of probiotic microbial strains in a cheese matrix during ripening: Simulation of rates of salt diffusion and microorganism survival. J. Food Eng. 36:281-301.

Hannon, J. A., M. G. Wilkinson, C. M. Delahunty, J. M. Wallace, P. A. Morrissey, and T. P. Beresford. 2005. Application of descriptive sensory analysis and key chemical indices to assess the impact of elevated ripening temperatures on the acceleration of Cheddar cheese ripening. Int. Dairy J. 15:263-273.

Hardy, J., J. Scher, H. E. Spinnler, E. Guichard, and J. C. Gripon. 2000. Physical and sensory properties of cheese. Pages 447-473 in Cheesemaking: From Science to Quality Assurance. A. Eck and J. C. Gillis, ed. Intercept Limited, Andover, UK.

Klein, N., A. Zourari, and S. Lortal. 2002. Peptidase activity of four yeast species frequently encountered in dairy products: Comparison with seven dairy bacteria. Int. Dairy J. 12:853-861.

Lawrence, R. C., L. K. Creamer, and J. Gilles. 1987. Texture development during cheese ripening. J. Dairy Sci. 70:1748-1760.

Le Quéré, J. L. 2011. Cheese flavor. Pages 675-684 in Encyclopedia of Dairy Sciences. Vol. 1, 2nd ed. J. W. Fuquay, P. F. Fox and P. L. H. McSweeney, ed. Elsevier Academic Press, London, UK.

Leclercq-Perlat, M.-N., F. Buono, H.-E. D. Lambert, H. E. Spinnler, and G. Corrieu. 2004a. Controlled production of Camembert-type cheeses: Part I. Microbiological and physico- chemical evolutions. J. Dairy Res. 71:346-354.

Leclercq-Perlat, M.-N., G. Corrieu, and H.-E. Spinnler. 2004b. The color of Brevibacterium linens depends on the yeast used for cheese deacidification . J. Dairy Sci. 87:1536-1544.

Leclercq-Perlat, M.-N., G. Corrieu, and H. E. Spinnler. 2007. Controlled production of Camembert-type cheeses: Part III. Free fatty acid evolutions. J. Dairy Res. 74:218-225.

Leclercq-Perlat, M.-N., D. Picque, and C. Monnet. 2013. Dynamics of Penicillium camemberti growth quantified by real-time PCR on Camembert-type cheeses at different conditions of temperature and relative humidity. J. Dairy Sci. 96:4031-4040.

Leclercq-Perlat, M.-N., D. Picque, H. Riahi, and G. Corrieu. 2006. Microbiological and biochemical aspects of Camembert-type cheeses depend on atmospheric composition in the ripening chamber. J. Dairy Sci. 89:3260-3273.

Leclercq-Perlat, M.-N., M. Sicard, I. C. Trelea, D. Picque, and G. Corrieu. 2012. Temperature and relative humidity influence the microbial and physicochemical characteristics of Camembert-type cheese ripening. J. Dairy Sci. 95:4666-4682.

Lecocq, J., M. Guéguen, and O. Coiffier. 1996. Importance de l'association entre Geotrichum candidum et Brevibacterium linens pendant l'affinage des fromages à croûte lavée. Sci. Aliments $16: 317-327$.

Lemoine, R. 2001. L'affinage, une étape décisive pour la qualité du fromage. Revue Laitière Française 614:73-85.

Lesage-Meessen, L., and B. Cahagnier. 1998. Mécanismes d'adaptation des micromycètes auxactivités de l'eau réduite. Pages 19-35 in Moisissures des Aliments peu Hydratés. Ch. 2: Sci. \& Tech. AgroAliment. B. Cahagnier, ed. Lavoisier Tec \& Doc, Paris, France.

Lenoir, J., G. Lamberet, J. L. Schmidt, and C. Tourneur. 1985. La maîtrise du bioréacteur Fromage. Biofutur 41:23-50.

McSweeney, P. L. H., and M. J. Sousa. 2000. Biochemical pathways for the production of flavor compounds in cheese during ripening: A review. Lait 80:293-324.

Noomen, A. 1983. The role of the surface flora in the softening of cheeses with a low initial pH. Neth. Milk Dairy J. 37:229-232.

Perrot, N., L. Agioux, I. Ioannou, G. Mauris, G. Corrieu, and G. Trystram. 2004. Decision support system design using the operator skill to control cheese ripening-application of the fuzzy symbolic approach. J. Food Eng. 64:321-333.

Picque, D., M. N. Leclercq-Perlat, and G. Corrieu. 2006. Effects of atmospheric composition on respiratory behavior, weight loss, and appearance of Camembert-type cheeses during chamber ripening. J. Dairy Sci. 89:3250-3259.

Picque, D., M. N. Leclercq-Perlat, H. Guillemin, T. Cattenoz, J. J. Provost, and G. Corrieu. 2010. Camembert-type cheese ripening 
dynamics are changed by the properties of wrapping films. J. Dairy Sci. 93:5601-5612.

Ramet, J. P. 2000. Comparing ripening technology of the various types of cheese. Pages 418-446 in Cheesemaking: From Science to Quality Assurance. A. Eck and J. C. Gillis, ed. Lavoisier Publishing, Paris, France.

Rattray, F. P., and P. F. Fox. 1999. Aspects of enzymology and biochemical properties of $B$. linens relevant to cheese ripening: A review. J. Dairy Sci. 82:891-909.

Sablé, S., and G. Cottereau. 1999. Current knowledge of soft cheeses' flavor and related compounds. J. Agric. Food Chem. 47:48254836 .

Sicard, M., N. Perrot, M.-N. Leclercq-Perlat, C. Baudrit, and G. Corrieu. 2011. Toward the integration of expert knowledge and instrumental data to control food processes: Application to Camemberttype cheese ripening. J. Dairy Sci. 94:1-13.
Sihufe, G. A., S. E. Zorrilla, N. G. Sabbag, S. C. Costa, and A. C. Rubiolo. 2010. The influence of ripening temperature on the sensory characteristics of Reggianito Argentino cheese. J. Sens. Stud. 25:91-107.

Simal, S., E. S. Sanchez, J. Bon, A. Femenia, and C. Rossello. 2001. Water and salt diffusion during cheese ripening: Effect of the external and internal resistances to mass transfer. J. Food Eng. 48:269-275.

Vassal, L., V. Monnet, D. Le Bars, C. Roux, and J. C. Gripon. 1986. Relation between $\mathrm{pH}$, chemical composition and texture of Camembert cheese. Lait 66:341-351.

Von Weissenfluh, A., and Z. Puhan. 1987. The effect of environmental conditions in the ripening room on the growth of Penicillium camemberti and the quality of Camembert cheese. Schweiz. Milchwirtsch. Forsch. 16:37-44. 